\title{
PENERAPAN PROSES PERENCANAAN KEPERAWATAN PADA PASIEN YANG MENDERITA DIABETES MELLITUS
}

\author{
SRI HARVITA SARI MARPAUNG / 181101125
}

Sriharvitaaasm@gmail.com

\begin{abstract}
ABSTRAK
Latar belakang : Dalam beberapa kasus jumlah penderita diabetes merupakan salah satu yang tertinggi penderitanya. Ini disebabkan karena banyak faktor yang dapat menyebabkan timbulnya penyakit diabetes mellitus. Oleh sebab itu, dalam proses keperawatan perencanaan keperawatan merupakan suatu hal yang penting untuk menyesuaikan penanganan masalah yang diderita oleh pasien berdasarkan diagnosa keperawatan sebelumnya sehingga dalam memberikan asuhan keperawatan perawat mampu menyesuaikannya dengan masalah yang diderita oleh pasien DM tersebut. Tujuan : untuk mengetahui proses perencanaan asuhan keperawatan kepada pasien yang menderita diabetes mellitus. Metode : menggunakan literature riview berdasarkan teks book, jurnal, e-book (10 tahun terakhir) dengan cara menganalisis, eksplorasi sumber dan kajian bebas. Hasil : memberikan informasi mengenai fungsi dari proses perencanaan asuhan keperawatan kepada pasien yang menderita diabetes mellitus berdasarkan diagnosa yang sebelumnya telah ditentukan serta untuk dapat melanjutkan proses keperawatan selanjutnya yaitu pelaksanaan (implementasi) dari perencanaan asuhan keperawatan tersebut. Pembahasan : pengertian asuhan keperawatan, masalah yang serig dijumpai pada pasien DM dan perencanaan asuhan keperawatan. Kesimpulan : Penerapan proses keperawatan dalam pemenuhan kebutuhan pasien sangatlah penting, salah satunya adalah proses perencanaan keperawatan dimana hal ini juga merupakan hal penting dalan pengambilan keputusan perawatan yang akan diberikan pada pasien tersebut.
\end{abstract}

Kata kunci : Diabetes mellitus, Perencanaan keperawatan, Asuhan keperawatan

\section{LATAR BELAKANG}

Diabetes melitus merupakan suatu penyakit dimana terjadi gangguan metabolisme karbohidrat, protein dan lemak. Hal ini diakibatkan oleh kurangnya sensitivitas otot ataupun jaringan terhadap insulin, yang disebut dengan resistensi insulin ataupun oleh kurangnya hormon insulin atau disebut dengan defisiensi insulin (Guyton \& Hall, 2007). Diabetes mellitus adalah suatu kumpulan gejala yang timbul pada seseorang disebabkan oleh adanya peningkatan kadar gula glukosa darah akibat kekurangan insulin baik absolut maupun relatif (Syahbudin, 2009). Bahaya diabetes sangat besar dan dapat memungkinkan penderita menjadi lemah ginjal, buta, menderita penyakit bagian kaki dan banyak komplikasi serius dan menyebabkan tingkat kematian yang tinggi. Penderita DM menghadapi bahaya setiap harinya karena kadar gula darah yang tidak 
terkontrol. Glukosa darah mengandung kadar yang berubah-ubah sepanjang hari terutama pada saat makan, dan beraktifitas (Pangestu, 2007).

Dalam beberapa kasus pasien penderita DM di berbagai rumah sakit yang ada, jumlah penderita diabetes merupakan salah satu yang tertinggi penderitanya. Ini disebabkan karena banyak faktor yang dapat menyebabkan timbulnya penyakit diabetes mellitus. Oleh sebab itu, dalam proses keperawatan perencanaan keperawatan merupakan suatu hal yang penting untuk menyesuaikan penanganan masalah yang diderita oleh pasien berdasarkan diagnosa keperawatan sebelumnya sehingga dalam memberikan asuhan keperawatan perawat mampu menyesuaikannya dengan masalah yang diderita oleh pasien DM tersebut.

\section{TUJUAN}

Tujuan dari penulisan ini adalah untuk mengetahui proses perencanaan asuhan keperawatan kepada pasien yang menderita diabetes mellitus.

\section{METODE}

Metode yang digunakan dalam penulisan ini menggunakan literature riview berdasarkan teks book, jurnal, e- book (10 tahun terakhir) dengan cara menganalisis, eksplorasi sumber dan kajian bebas.

\section{HASIL}

Hasil yang diharapkan dalam penulisan ini adalah untuk memberikan informasi mengenai fungsi dari proses perencanaan asuhan keperawatan kepada pasien yang menderita diabetes mellitus berdasarkan diagnosa yang sebelumnya telah ditentukan serta untuk dapat melanjutkan proses keperawatan selanjutnya yaitu pelaksanaan (implementasi) dari perencanaan asuhan keperawatan tersebut. Sehingga kebutuhan dasar pasien dapat tepat terpenuhi dan derajat kesehatan pasien meningkat.

\section{PEMBAHASAN}

Perencanaan proses keperawatan merupakan catatan yang berisi tentang catatan intervensi dan rencana keperawatan. Rencana asuhan keperawatan adalah pengkajian yang dilakukan untuk menentukan masalah yang sistematis dan penentuan tujuan serta berisi tentang strategi pemecahan masalah. Perencanaan keperawatan merupakan adalah penyusunan rencana tindakan keperawatan yang akan 
dilaksanakan untuk mengatasi masalah sesuai dengan diagnosa keperawatan yang telah ditentukan dengan tujuan terpenuhinya kebutuhan pasien.

Dalam melakukan perencanaan keperawatan perlu ditetapkan berdasarkan :

\section{a. Menentukan Prioritas}

Dalam menentukan perencanaan perlu disusun suatu sistem untuk menentukan diagnosa yang akan diambil pertama kali, dan dalam menyusun perencanaan asuhan keperawatan harus berdasarkan pada kebutuhan dasar manusia sehingga dalam pemenuhannya kebutuhan pasien terpenuhi. Dengan mengidentifikasi prioritas kelompok diagnosa keperawatan perawat dapat memprioritaskan masalah yang akan diatasi. Seperti dapat membedakan prioritas diagnosa yang merupakan diagnosa keperawatan atau masalah keperawatan, yang dimana jika tidak diatasi saat langsung akan berdampak buruk terhadap keadaan fungsi dan status kesehatan pasien, dengan diagnosa yang terpenting yang merupakan diagnosa keperawatan atau masalah kolaburatif dimana intervensi dapat ditunda utnuk beberapa saat tanpa berdampak terhadap status fungsi kesehatan.

\section{b. Menetapkan Tujuan}

Tujuan dari perawatan merupakan pedoman dimana pasien diharapkan mengalami kemajuan dalam berespon terhadap tindakan perawatan yang diberikan. Tujuan dibedakan menjadi dua, yaitu :

- Tujuan jangka panjang yaitu tujuan yang mengidentifikasi arah keseluruhan atau hasil akhir perawatan. Tujuan ini tidak tercapai sebelum pemulangan. Tujuan jangka panjang memerlukan perhatian yang terus menerus dari pasien dan/atau orang lain. Tujuan yang diharapkan dapat dicapai dalam waktu yang lama, biasanya lebih dari satu minggu atau satu bulan. Kriteria hasil dalam tujuan jangka panjang ditujukan pada unsur problem/masalah dalam diagnosa keperawatan.

- Tujuan jangka pendek yaitu tujuan yang harus dicapai sebelum pemulangan.

\section{c. Menentukan Kriteria Hasil}

Kriteria hasil untuk diagnosa keperawatan mewakili status kesehatan 
klien yang dapat dicapai atau dipertahankan melalui rencana tindakan yang mandiri, sehingga dapat membedakan antara diagnosa keperawatan dan masalah kolaburatif. Menurut Gordon(1994), komponen kriteria hasil yang penting dalam kriteria hasil adalah apakah intervensi keperawatan dapat dicapai. Dalam pembuatan kriteria hasil diharapkan harus berpedoman pada :

$\checkmark$ Berfokus pada pasien

$\checkmark$ Singkat dan jelas

$\checkmark$ Dapat diobsevasi dan diukur

$\checkmark$ Ada batas waktu

$\checkmark$ Realistik yaitu kriteria hasil harus dicapai sesuai dengan saran dan prasarana yang tersedia.

$\checkmark$ Ditentukan oleh perawat dan klien

Perencanaan asuhan keperawatan pada pasien diabetes mellitus dirancang sesuai dengan permasalahan yang dialami oleh pasien tersebut, sehingga dalam pengimplemantasiannya dapat dimaksimalkan. Beberapa masalah dan perencanaan keperawatan yang dapat dilakukan pada pasien diabetes mellitus yaitu :
I. Diagnosa I : gangguan perfusi jaringan berhubungan dengan melemahnya/menurunnya aliran darah kedaerah gangren akibat adanya obstruksi pembuluh darah. Tujuan : Tujuan : mempertahankan sirkulasi perifer tetap normal.

Kriteria hasil : Denyut nadi perifer teraba kuat dan regular, warna kulit sekitar luka tidak pucat/sianosis, kulit sekitar luka teraba hangat, oedema tidak terjadi dan luka tidak bertambah parah, sensorik dan motorik membaik.

Rencana asuhan keperawatannya yaitu :

- Ajarkan pasien untuk melakukan mobilisasiRasional : dengan mobilisasi meningkatkan sirkulasi darah.

- Ajarkan tentang faktor-faktor yang dapat meningkatkan aliran darah : tinggikan kaki sedikit lebih rendah dari jantung, hindari penyilangkan kaki, hindari balutan ketat, hindaripenggunaan bantal, di belakang lutut dan sebagainya.

- Ajarkan tentang modifikasi faktor-faktor resiko berupa : hindari diet tinggi kolestrol, teknik relaksasi, menghentikan 
kebiasaanmerokok, dan penggunaan obat vasokontriksi. Rasional : kolestrol tinggi dapat mempercepat terjadinya arterosklerosis, merokok dapat menyebabkan terjadinya vasokontriksi pembuluh darah,relaksasi untuk mengurangi efek dari stres.

- Kerja sama dengan tim kesehatan lain dalam pemberian vasodilator,pemeriksaan gula darah secara rutin dan terapi oksigen ( $\mathrm{HBO}$ ). Rasional : pemberian vasodilator akan meningkatkan dilatasi pembuluh darahsehingga perfusi jaringan dapat diperbaiki, sedangkan pemeriksaan guladarah secara rutin dapat mengetahui perkembangan dan keadaan pasien, HBOuntuk memperbaiki oksigenasi daerah ulkus/gangrene.

II. Diagnosa II : Kurangnya pengetahuan tentang proses penyakit, diet, perawatan, danpengobatan berhubungan dengan kurangnya informasi. Tujuan : Pasien memperoleh informasi yang jelas dan benar tentang penyakitnya.
Kriteria hasil : Pasien mengetahui tentang proses penyakit, diet, perawatan dan pengobatannya dan dapat menjelaskan kembali bila ditanya dan pasien dapat melakukan perawatan diri sendiri berdasarkan pengetahuan yang diperoleh.

Rencana asuhan keperawatan :

- Kaji tingkat pengetahuan pasien/keluarga tentang penyakit DM dan gangren. Rasional : untuk memberikan informasi pada pasien/keluarga, perawat perlu mengetahui sejauh mana informasi atau pengetahuan yang diketahui pasien/keluarga.

- Kaji latar belakang pendidikan pasien. Rasional : agar perawat dapat memberikan penjelasan dengan menggunakankata-kata dan kalimat yang dapat dimengerti pasien sesuai tingkat pendidikan pasien.

- Jelaskan tentang proses penyakit, diet, perawatan dan pengobatan padapasien dengan bahasa dan kata-kata yang mudah dimengerti. Rasional : agar informasi dapat diterima dengan mudah dan tepat 
sehinggatidak menimbulkan kesalahpahaman.

- Jelasakan prosedur yang kan dilakukan, manfaatnya bagi pasien dan libatkanpasien didalamnya. Rasional : dengan penjelasdan yang ada dan ikut secra langsung dalamtindakan yang dilakukan, pasien akan lebih kooperatif dan cemasnyaberkurang.

- Gunakan gambar-gambar dalam memberikan penjelasan (jika ada /memungkinkan). Rasional : gambar-gambar dapat membantu mengingat penjelasan yangtelah diberikan.

III. Diagnosa III : Gangguan pemenuhan nutrisi ( kurang dari ) kebutuhan tubuh berhubungandengan intake makanan yang kurang. Tujuan : Kebutuhan nutrisi dapat terpenuhi.

Kriteria hasil : . Berat badan dan tinggi badan ideal, pasien mematuhi dietnya, kadar gula darah dalam batas normal, tidak ada tanda-tanda hiperglikemia/hipoglikemia.

Rencana asuhan keperawatan :

- Kaji status nutrisi dan kebiasaan makan. Rasional : untuk mengetahui tentang keadaan dan kebutuhan nutrisi pasiensehingga dapat diberikan tindakan dan pengaturan diet yang adekuat.

- Anjurkan pasien untuk mematuhi diet yang telah diprogramkan. Rasional : kepatuhan terhadap diet dapat mencegah komplikasi terjadinyahipoglikemia/hiperglik emia.

- Timbang berat badan setiap seminggu sekali. Rasional : mengetahui perkembangan berat badan pasien (berat badan merupakan salah satu indikasi untuk menentukan diet).

- Identifikasi perubahan pola makan. Rasional : mengetahui apakah pasien telah melaksanakan program diet yang ditetapkan.

- Kerja sama dengan tim kesehatan lain untuk pemberian insulin dan diet diabetic

Berdasarkan perencanaan yang dibuat berdasarkan pedoman diagnosa keperawatan maka perencanaan asuhan keperawatan dapat ditetapkan sesuai dengan kebutuhan pasien sehingga 
kebutuhan pasien terpenuhi dan kesehatan pasien akan meningkat.

Jauhar, M. (2013). Asuhan Keperawatan. Jakarta : Prestasi Pustaka KESIMPULAN

Penerapan proses keperawatan dalam pemenuhan kebutuhan pasien sangatlah penting, salah satunya adalah proses perencanaan keperawatan dimana hal ini juga merupakan hal penting dalan pengambilan keputusan perawatan yang akan diberikan pada pasien tersebut. Dalam memberikan asuhan keperawatan kepada pasien yang menderita diabetes mellitus perlu diketahui masalah apa yang dialami oleh pasien sehingga perawatan yang diberikan tepat mengenai sasaran masalah yang ingin diatasi dan pasien akan mengalami kemajuan kesehatan.

\section{REFERENSI}

Almatsier, S. (2004). Penuntun Diet

Edisi Baru. Jakarta : PT Gramedia

Pustaka Utama.

Arjatmo. (2002). Penatalaksanaan

Diabetes Mellitus Terpadu Cetakan 2. Jakarta : Balai Penerbit FKUI.

Hutagalung H. (2004). Karbohidrat.

Bagian Ilmu Gizi Fakultas Kedokteran Universitas Sumatra Utara : USU digital library. Hal : 1-13.

Hincliff. (1999). Kamus Keperawatan. Jakarta : EGC.

Maulana, M. (2008). Mengenal Diabetes Melitus. Jogjakarta : Perpustakaan Nasional KDT.

Mubarak, W. I., Indrawati, L., Susanto, J. (2015). Buku Ajar Ilmu Keperawatan Dasar. Jakarta : Salemba Medika.

Nurarif, A. H. (2015). Aplikasi Asuhan Keperawatan Berdasarkan Diagnosa Medis dan NANDA NIC - NOC. Yogyakarta : Media Action.

Perkeni. (2006). Konsensus Pengelolaan dan Pencegahan Diabetes Melitus Tipe 2 di Indonesia. Jakarta : EGC.

Potter \& Perry. (2010). Fundamental of Nursing (fundamental Keperawatan). Buku 1. Edisi 7. Indonesia : Salemba Medika.

Potter \& Perry. (2010). Fundamental of Nursing (fundamental Keperawatan). Buku 3. Edisi 7. Indonesia : Salemba Medika.

Soegondo, S. Dkk. (2007). Penatalaksanaan Diabetes Mellitus Terpadu Cetakan 6. Jakarta : Balai Penerbit FKUI. 
Supariasa,dkk. (2002). Penilaian Status Gizi. Jakarta : EGC.

Wilkinson, J. M.(2017). Diagnosa

Keperawatan Edisi 10. Jakarta : EGC. 